\title{
If Looks Could Kill: Looking through the Artist's Lenses in Oscar Wilde's The Picture of Dorian Gray (1891)
}

\author{
Abdelfattah Ali Ghazel \\ Department of English, College of Education Zulfi \\ Majmaah University \\ Majmaah, Saudi Arabia
}

\begin{abstract}
:
This paper investigates aestheticism and authorship in the Oscar Wilde's only novel The Picture of Dorian Gray (1891). Victorian literature is usually read against the relationship between art and reality. The literary merit of a book is determined by the degree of its conformity with the moral values of the time. This paper offers a detached reading of the novel where the value of the book is found in its ability to initiate the reader into an aesthetic world. The research argues that Wilde fragments the act of artistic creation among the artist (the painter Basil), the sitter (Dorian Gray) and the audience (Lord Henry Wotton). This fragmentation renders the novel aesthetically autonomous from its reality. Aesthetic autonomy contributes to the debate of morality in Victorian literature by placing the work of art in an alternative sphere where normative values cease to apply.
\end{abstract}

Key words: aesthetic autonomy, authorship, realism, subject positions, Victorian morality

Cites as: Ghazel, A. A. (2019). If Looks Could Kill: Looking through the Artist's Lenses in Oscar Wilde's The Picture of Dorian Gray (1891). Arab World English Journal for Translation \& Literary Studies, 3 (1) 136-144 . DOI: http://dx.doi.org/10.24093/awejtls/vol3no1.11 